\title{
Minimal number of procedures: resident's point of view
}

\author{
Volha Raznitsyna $^{1}$, Alexander Lemeschewskij ${ }^{\wedge}$ \\ ${ }^{1}$ Department of General Surgery, Mogilev City Hospital No. 1, Mogilev, Belarus; ${ }^{2}$ Department of General Surgery, Belarusian State Medical \\ University, Minsk, Belarus \\ Contributions: (I) Conception and design: V Raznitsyna; (II) Administrative support: None; (III) Provision of study materials or patients: A \\ Lemeschewskij; (IV) Collection and assembly of data: A Lemeschewskij; (V) Data analysis and interpretation: V Raznitsyna; (VI) Manuscript writing: \\ Both authors; (VII) Final approval of manuscript: Both authors. \\ Correspondence to: Dr. Volha Raznitsyna, MD. Department of General Surgery, Mogilev City Hospital No. 1, Av. Dimitrova 39-14, Mogilev 212040, \\ Belarus. Email: olga.razni@mail.ru.
}

\begin{abstract}
Every generation of young surgeons faces difficulties in the educational process. But the main questions to answer are constant: the duration of residency training, the organization of the educational process, the habilitation of mentors, and essentially how many procedures a resident should perform during training period. The aim of this opinion article is to discuss the number of procedures that surgical trainees should perform during internship or residency. We reviewed the official program of internship/residency in Belarus and other countries, trying to reveal hidden pitfalls of learning in the operation room (impossibility to establish the standards, a need of waiting for a certain patient with a certain problem to perform a certain procedure; danger for a patient and stress for a mentor) and make some suggestions how to improve the training process, especially in restricted conditions (practicing the simplest procedures as much as possible, using handmade simulators, etc.). In conclusion, the necessary number of procedures for the residents depends on the period of surgical training, availability of simulators, basic manual skills of a resident. The assessment scales should be widely used. The main goal for the education of the specialist is to provide safety for all the participants of surgery (a patient, a resident and his mentor).
\end{abstract}

Keywords: Surgical trainee; residency; education; simulators; practical skills

Received: 08 May 2021; Accepted: 15 June 2021; Published: 30 September 2021.

doi: 10.21037/asj-21-30

View this article at: https://dx.doi.org/10.21037/asj-21-30

\section{Introduction}

The process of medical education is continuous and never ends. After graduation from the medical school, a new great step starts. During this period, a young specialist needs to learn how to apply knowledge to real patient's care. There are more obstacles to surgeons since the acquisition of practical skills depends on surrounding conditions, such as who will teach, how and for how long. The aim of this opinion article is to discuss the number of procedures that surgical trainees should perform during internship or residency.

\section{Goals during surgical training}

In our opinion, the main general goals for surgical practical education are:

(I) To assign the self-assurance of the future surgeon for the performance of a standard operation.

(II) To become a qualified assistant.

(III) To learn how to manage the most typical surgical cases.

(IV) To provide patient safety.

(V) To reduce stress for the young surgeon's mentor.

^ ORCID: 0000-0001-8834-0605. 
Table 1 Some data taken from official educational programs for general surgery trainee in the USA (4), Russia (5) and Belarus (6)

\begin{tabular}{lccc}
\hline Countries & How long & Simulators use & Assessment scales \\
\hline Belarus (internship) & 1 year & $+/-$ (only for intensive care procedures) & - \\
Russia (residency) & 2 years & + & $+($ for skill) \\
USA (residency) & 5 years & + & + (for procedures) \\
\hline
\end{tabular}

Second, the procedures can be divided in those that can be practiced by their own and those, which need a special equipment and should be performed under control [the simplest, general medical and specialized procedures (1)].

(I) Tying knots, suturing superficial tissues, etc.

(II) Arterial and central venous line placement, abdominal paracentesis, arthrocentesis, etc.

(III) Performing operative approach, different steps of each kind of abdominal (or other) surgery, etc.

In case of well-organized training process and wellequipped centers (or rooms) all the procedures should be performed on the simulators with a control of a mentor after $(2,3)$. In many countries simulator training is widely spread in post-graduate education $(4,5)$, in some countries it isn't (6).

Third, training must occur within desirable conditions:

(I) Enough time.

(II) A good tutor.

(III) An individual training program that allows flexibility and has an assessment scale.

(IV) Simulators, that not only allow to acquire skills (7), but also to refresh skills after a long absence at work (after holidays, for example) to make a process of training more objective, safe and less persondependent.

(V) An extremely debatable point of possible use of animals (alive and corpses) and human corpses for training (7).

It is obvious, that completing all the perfect conditions the healthcare system has more chances to raise a good specialist, who is capable to act on its own, even though every surgery is unique. But the question remains: how many procedures are enough for a resident in training?

This question has probably no single answer. It is unique for every healthcare system and depends on:

* The period that the residency lasts;

* How available the simulators are (if they are);

* What assessment scale is used to evaluate the skills;

* What goal is desirable to achieve at the end.

In relation to the last point, it can be said that very often reality appears to be much more far from the educational program aim and it is difficult to prepare an autonomous surgeon in limited conditions (6) and it is better to have a list of certain skills which are easy to assess.

\section{Experience around the globe}

Table 1 shows some data from the official educational programs for general surgery trainee in the USA (4), Russia (5) and Belarus (6).

According to these programs, in Belarus a trainee is expected to perform 11-18 abdominal surgeries by his/her own (appendectomy and hernia repair) and around 52-76 as an assistant (including other abdominal surgeries) (6). In Russia the number of procedures is not determined (5). In the USA a minimum number of procedures for applying for the board certificate is 850 (from different surgical areas) (4). According Canadian Residency Training Program a trainee is expected to perform 15 appendectomies, 15 cholecystectomies, 20 groin hernia repairs by the second year (8). In this Program, there is a determined number of some procedures which can be performed in the skill lab (8), for example, hand sewn and stapled bowel anastomosis -3 and 3 . For the majority of procedures there are no minimum numbers to perform on simulators specified in the Training programs of the countries.

It is possible to assess required skills only if we have simulators and established assessment scale. The resident demonstrates the satisfying managing of demanded skill and he is admitted to the clinical stage (9). There are also different opinions based on the point of view of the trainer or the trainee. In internal medicine, performing a procedure in average 6-10 times is enough to achieve a comfortable level of confidence, but some of them require more repetitions [50-200] (10). These numbers came from different studies which involved feedback from residents, whereas the official minimum number for each procedure was much less (10).

If simulators are not available, the situation becomes 


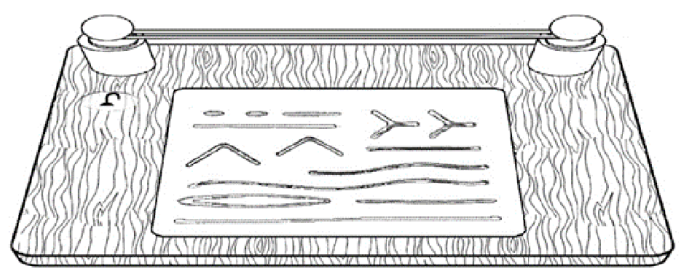

Figure 1 Hand-made simulator for suturing and knotting.

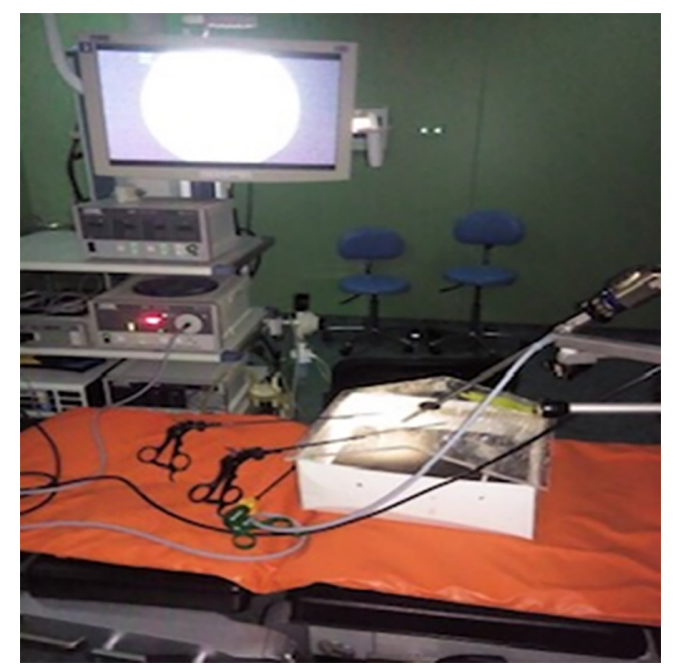

Figure 2 Hand-made laparoscopic simulator from Mogilev Regional Infant Hospital.

more difficult. Many countries cannot provide the accessibility for all centers due to costs (equipment and supplies). Moreover, simulator centers are a recent development as compared to the whole history of the surgical art. For example, Belarusian State Medical University acquired simulators only in 2015.

\section{Hidden pitfalls of learning in the operation room}

* Impossibility to establish the standards, because every operation is unique;

* A resident should wait for a certain patient with a certain problem to perform a certain procedure;

* Danger for a patient and stress for a mentor.

Acting on a real operation should be a final step of the education, because a resident takes the most valuable tips from his mentor (11), when he or she is technically prepared and know not only the steps of the operation but also his role as an assistant (8).

\section{A way to train in restricted conditions}

So, what is possible to do in the conditions of the lack of simulators or time?

(I) There are plenty of manual techniques that can be trained even in the middle of studying (12) and which do not need special theoretical education, patients or even tutors, which are so called basic procedures (Figure 1). How many knots should a future surgeon make? As many as possible! There are a lot of ways of self-evaluation, for example, the rate (knot per minute).

(II) Several advanced exercises can also be performed by residents or students, for example, suturing tissues or parts of dressed chicken, simple intestine anastomosis, but they require tools and material (animal intestine, for example). Such techniques are rather popular among student groups of interests.

(III) Using advanced handmade simulators (for example, for laparoscopy) (Figure 2).

(IV) Some techniques can be also trained on different practices during the studying, they are rather simple to perform and do not carry a big risk for the patient.

(V) Practical training on simulators is included in educational programs of medical students, but their use sometimes is limited (13).

But, even if a resident perfectly performs all these exercises there is no acceptable assessment of his skills, because they are not standardized and unusual, so there can be no belief to the level of his training. A resident has a chance only if a mentor confides in the young colleague and allows demonstrate a new acquired skill during the operation.

To facilitate the process of studying in real operation room, we offer to separate out typical procedures that repeat from operation to operation for both abdominal and laparoscopic (9) surgery.

Typical procedures for abdominal surgery:

* Laparotomy (different types of approach);

* Abdominal cavity revision;

* Drainage of cavities (after the operation and in acute situations);

* Performing of gastric and intestine suture.

These procedures repeat from operation to operation, almost independently of their type. It allows the resident to participate actively, performing the step, without the need to wait for a simple operation. It also makes easier the 
next stage: such operations as appendectomy, herniotomy, cholecystectomy should be also divided into classical steps (14) and every step should be repeated by resident several times. Thanks to the added skills, in these operations the resident will have a possibility to concentrate on more specific things.

Familiar steps should be performed by the resident every time when it is possible (for example, cholecystectomy during the Whipple's procedure).

In case of intestine anastomosis, it is better to use machine stitch to prevent possible complications and to achieve identical performing.

In modern conditions, do we need to pay more attention to laparoscopic or robotic surgery use? Especially in cases when it is rarer to see traditional appendectomy than laparoscopic (15). If the Health system allows, a resident should learn on everything that's possible step by step.

\section{Student surgical Olympiad}

In some countries, including Russia and Belarus, medical universities hold competitions in surgical practical skills and theoretical knowledge among interested studentssurgical Olympiad (16). Such a type of optional surgical pregraduate training grew from the simplest procedures that were practiced in small student groups to a big international annual event where future doctors demonstrate advanced operations (vascular suturing, intestinal anastomoses, microsurgical techniques, video endoscopy) which are performed on simulators and animals $(16,17)$. The aims of the Olympiad are to raise interest to surgical specialties, find talented youth and form a personnel reserve (17). It is also a good way to develop practical skills of the future surgeon.

\section{Conclusions}

(I) It is difficult to establish a needed number of procedures for the residents without using simulators and the assessment scales.

(II) A number of procedures will depend on residency duration, available equipment, individual characteristics of the resident.

(III) Feedback from residents (for example, questionnaires) is important to establish a real number of needed procedures.

(IV) As many mentors as possible should participate in working out educational programs for Healthcare system and the assessment scales.
(V) It is better to perform definite steps of surgery perfectly than the whole operation uncertainly (especially in case of time and equipment restrictions), so may be some educational programs need to be revised according to their restrictions.

(VI) Residency is a limited period of time in any case. It is time of focusing on the most important basic things in each surgical discipline. A surgeon keeps studying for the whole life.

(VII) Even if there are no available modern simulators, there are a lot of ways to improve manual skills.

(VIII) If countries hold surgical skills competitions, the certificates of professional training should be worked out.

(IX) Safety comes first.

\section{Acknowledgments}

Funding: None.

\section{Footnote}

Provenance and Peer Review: This article was commissioned by the editorial office, AME Surgical Fournal for the series "Modern Challenges in the Education of Young Surgeons: the Two Sides of the Coin". The article has undergone external peer review.

Peer Review File: Available at https://asj.amegroups.com/ article/view/10.21037/asj-21-30/prf

Conflicts of Interest: Both authors have completed the ICMJE uniform disclosure form (available at https://asj.amegroups. com/article/view/10.21037/asj-21-30/coif). The series "Modern Challenges in the Education of Young Surgeons: the Two Sides of the Coin" was commissioned by the editorial office without any funding or sponsorship. VR served as an unpaid Guest Editor of the series. The authors have no other conflicts of interest to declare.

Ethical Statement: The authors are accountable for all aspects of the work in ensuring that questions related to the accuracy or integrity of any part of the work are appropriately investigated and resolved.

Open Access Statement: This is an Open Access article distributed in accordance with the Creative Commons Attribution-NonCommercial-NoDerivs 4.0 International 
License (CC BY-NC-ND 4.0), which permits the noncommercial replication and distribution of the article with the strict proviso that no changes or edits are made and the original work is properly cited (including links to both the formal publication through the relevant DOI and the license). See: https://creativecommons.org/licenses/by-nc-nd/4.0/.

\section{References}

1. Grigoriev NN, Bobrovskaya EA, Grigoriev SN. Topical issues of technology of teaching surgery. Modern problems of science and education. 2016. Available online: https:// science-education.ru/ru/article/view?id=24912

2. Datta V, Bann S, Aggarwal R, et al. Technical skills examination for general surgical trainees. Br J Surg 2006;93:1139-46.

3. Mackay S, Datta V, Chang A, et al. Multiple Objective Measures of Skill (MOMS): a new approach to the assessment of technical ability in surgical trainees. Ann Surg 2003;238:291-300.

4. The American Board of Surgery. Booklet of Information Surgery 2020-2021. Available online: https://www. absurgery.org/xfer/BookletofInfo-Surgery.pdf

5. Ministry of Health of the Russian Federation. Training of highly qualified personnel in residency. Industrial (clinical) practice program 1. 2016. Available online: https:// rsmu.ru/academics/clinical-residency/obrazovatelnyeprogrammy-i-uchebnye-plany-ordinatury/

6. Ministry of Health of the Republic of Belarus. Internship program (surgery). 2018. Available online: http://minzdrav. gov.by/ru/dlya-spetsialistov/kadry-i-obrazovanie/ internatura/plany-i-programmy-internatury-2014-god. php?clear_cache=Y

7. Palter VN, Grantcharov TP. Simulation in surgical education. CMAJ 2010;182:1191-6.

8. Ahmed N, Palmer S. Residency training program orientation guide. 2016. Available online: https://surgery. utoronto.ca/file/692/

9. Gorshkov MD, Sovtsov SA, Matveev NL.

doi: $10.21037 /$ asj-21-30

Cite this article as: Raznitsyna V, Lemeschewskij A. Minimal number of procedures: resident's point of view. AME Surg J 2021;1:14.
Admission of residents to endosurgical operating theatre. What are the basic preclinical laparoscopic skills you can learn beyond surgical unit? Endoskopicheskaya Khirurgiya 2016;22:38-45. Available online: https://www.mediasphera.ru/issues/ endoskopicheskaya-khirurgiya/2016/1/downloads/ $\mathrm{ru} / 1102572092016011038$

10. Flannery MT, Zahorsky S. Simulation in residency training: a review. Creative Education 2014;5:31-5.

11. Whalan C. Assisting at surgical operations: a practical guide. Cambridge: Cambridge University Press, 2006.

12. Rüsseler $M$, Weber R, Braunbeck A, et al. Training of practical clinical skills in surgery-a training concept for medical students. Zentralblatt Fur Chirurgie 2010;135:249-56.

13. Rednenko VV, Babenkova LV, Barkun GK. Practicing practical skills and abilities. Standards of simulation modules for medical care. 2016. Available online: https:// elib.vsmu.by/handle/123/11092

14. Littmann I. Operative surgery under the general editorship of prof. I. Littmann. 3d ed. Budapest: Hungary Academy of Sciences publishing, Budapest, 1985.

15. Silvennoinen M. Learning Surgical Skills with Simulator Training: Residents' Experiences and Perceptions. 2011. Available online: http://proceedings.informingscience.org/ InSITE2011/InSITE11p545-566Silvennoinen231.pdf

16. Dydykin S, Kapitonova M. The role of student surgical interest groups and surgical Olympiads in anatomical and surgical undergraduate training in Russia. Anat Sci Educ 2015;8:471-7.

17. Supplement No. 1 to the order of the Federal State Budgetary Educational Institution of Higher Education BSMU of the Ministry of Health of Russia dated February 17, 2020 No. 69-a Regulations on the procedure for organizing and holding the All-Russian Student Olympiad in Surgery with international participation. 2020. Available online: https://www.bashgmu.ru/education/ vserossiyskaya-studencheskaya-olimpiada-po-khirurgii-smezhdunarodnym-uchastiem-/ 